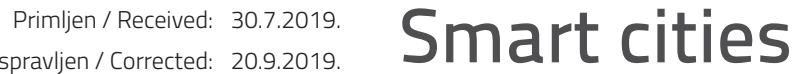

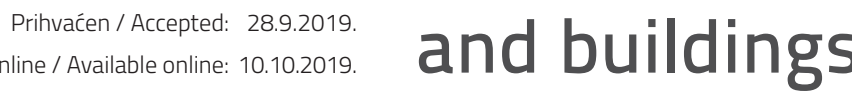

Authors:

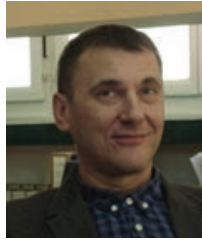

Assist.Prof. Silvio Bašić, PhD. Arch

University of Zagreb

Faculty of Civil Engineering

Department of Buildings

sbasic@grad.hr

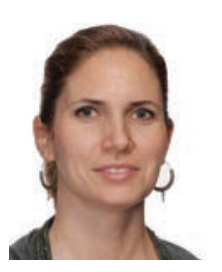

Assist.Prof. Nikolina Vezilić Strmo, PhD. Arch University of Zagreb

Faculty of Civil Engineering

Department of Buildings

nvezilic@grad.hr

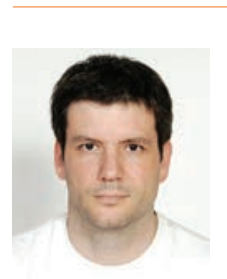

Marinko Sladoljev, MArch University of Zagreb Faculty of Civil Engineering Department of Buildings msladoljev@grad.hr
Silvio Bašić, Nikolina Vezilić Strmo, Marinko Sladoljev

Subject review

\section{Smart cities and buildings}

Over little more than 30 years, smart cities and buildings have evolved, from an intriguing vision and interesting concept, to a globally present phenomenon. The difference between an intelligent and "traditional" (sustainable) city/building can be seen, first of all, in the presence of intelligent services system representing a new layer in the totality of urban fabric or building structure. Its particularity lies in the fact that it is complex, susceptible to changes, and capable of learning (evolving).

Key words:

smart city, smart building, smart utility system, sustainability, features

Pregledni rad

Silvio Bašić, Nikolina Vezilić Strmo, Marinko Sladoljev

\section{Pametni gradovi i zgrade}

Pametni gradovi i zgrade u proteklih su nešto više od 30 godina, od intrigantne vizije i zanimljivog koncepta, postali globalno prisutan fenomen. Razlika između pametnog i "tradicionalnog" (održivog) grada/zgrade očituje se, prije svega, u prisutnosti pametnog uslužnog sustava koji predstavlja novi sloj u ukupnosti urbanog tkiva ili strukture zgrade. Njegova posebnost leži u činjenici da je kompleksan, podložan promjenama i sposoban je učiti (evoluirati).

Ključne riječi:

pametan grad, pametna zgrada, pametni uslužni sustav, održivost, obilježja

Übersichtsarbeit

Silvio Bašić, Nikolina Vezilić Strmo, Marinko Sladoljev

\section{Intelligente Städte und Gebäude}

In etwas mehr als 30 Jahren sind intelligente Städte und Gebäude aus einer faszinierenden Vision und einem interessanten Konzept zu einem weltweit vorherrschenden Phänomen geworden. Der Unterschied zwischen einer intelligenten und einer "traditionellen" (nachhaltigen) Stadt/einem Gebäude zeigt sich zuallererst im Vorhandensein eines intelligenten Dienstleistungssystems, das eine neue Schicht in der Gesamtheit des städtischen Gewebes und in der Gesamtstruktur des Gebäudes darstellt. Seine Besonderheit liegt in der Komplexität, Veränderungsfähigkeit und Lernfähigkeit.

Schlüsselwörter:

Smart City, Smart Building, Smart Utility System, Nachhaltigkeit, Funktionen 


\section{Introduction}

By 2025 , about $58 \%$ of the world's population or 4.6 billion people are expected to live in urban areas. In developed regions, urban population could account for as many as $81 \%$ of the total population. This estimate represents serious challenges to planners who will have to consider how to ensure the quality of life for the growing urban population in a sustainable way [1]. Although the concepts of smart city and smart building are a possible answer to this sensitive question, general consensus has still not been reached on what a smart city or smart building actually is, which makes it difficult to understand and agree on the meaning of the concept of smart city or smart building.

A study of abundant literature that has emerged over the past 30 years shows that, as a rule, at least one chapter is devoted to exploring the meaning of particular definitions, which are then compared in order to point out the divergence resulting from different approaches and assumptions used in such definitions. The concept of a smart city - was shaped in two stages. At an early stage, in the 1985-2000, the definition of the smart city concept was developed in parallel with definitions of similar or quasi-similar concepts such as: intelligent city [2], digital city [3], technocity [4], cybercity [5], and others.

This initial literature on smart, intelligent, digital, techno, and cyber cities was characterized by the juxtaposition of innovation and information technology, and a virtual and physical city. Specifically, in the concepts of an intelligent and smart city, the city is considered to be a complex physical, social, and digital entity where a particular focus is placed on innovation and information technology (hereinafter: ICT), while in the concepts of digital and cyber city, it is a city in cyber space with an emphasis on e-administration and virtual representation.

The second phase has been in progress as from 2000 and is characterized by more correct use and more accurate definition of the term smart city in the urban development and planning literature [6], as well as by the divergence of definitions, which makes it difficult to reach a common understanding and agreement on the meaning of the smart city concept. Apart from the common reference to ICT as an instigator of smart city development, these definitions are different in nature, and the division they create becomes even more apparent when attempts are made to discover a generally accepted interpretation of smart city functioning modalities, and of the fields of influence of such cities, as highlighted in a number of publications [7]. It is however clear that an excessive number of definitions can result in a lack of focus, which can blur the really important factors of a smart city.

The concept of smart building - originally, the term intelligent building was used in the United States in the early 1980s and was defined by the Intelligent Building Institution as follows: An intelligent building is the one which integrates various systems to effectively manage resources in a coordinated mode to maximise: technical performance; investment and operating cost savings, and flexibility [8].
However, although this is a significantly different scale compared to a smart city, the number of definitions soon began to emerge. The research conducted by Wigginton and Harris until 2002 already provided more than thirty different definitions of the term intelligent building [9].

What is important to emphasize for the smart building concept is that early definitions of the concept, as in smart cities, mainly focused on the role of technology, and later on, from the late 1990 s, they have gradually changed in that a greater emphasis is placed on the role of user interactions and social context, with the focus on the quality of life $[9,10]$.

The terms smart city and smart building are both related to management systems (ICTs) that are used to create a quality environment. However, we are dealing here with two levels of a partly similar problem, both functioning in synergy.

Many experts and scholars from a variety of scientific fields have been using a number of distinct approaches to tackle this issue, which has resulted in a great divergence of definitions. For this reason, and in order to better understand the concepts of smart city / building, it is necessary to clarify the circumstances of their creation (genesis of the concept), and to define working definitions and basic characteristics, before actually considering possible challenges related to their future development.

\section{Genesis of the concept}

The concept of a smart city draws its origins from the cities of science, technopolises of the first half of the $20^{\text {th }}$ century, or technopoles of the second half of the $20^{\text {th }}$ century. At the end of the first half of the $20^{\text {th }}$ century, Stanford University rector Frederick Terman established a development park in the immediate vicinity of the University, attracting high technology companies [11]. The area was named Stanford Industrial Park and it is located in the area known today as Silicon Valley which has become, thanks to the Stanford Industrial Park development, the first technopole.

High technology (R\&D, production) has not only encouraged economic development and attractiveness of the area, but has also offered a specific model of urbanity - a technopole. According to Castells and Hall [13], technopoles are cities, suburbs or even rural areas dominated by the presence of high technology in the form of research, development, production or some combination of these three factors. A successful technopole is characterized by the synergy of industry, academia and governments (or in this case, the computer industry, Stanford University, and government).

What has been recognized as different and innovative in the planning / organizational sense is that technopoles require an environment that is inspiring and supportive for those who develop new technologies which, historically, is not such a new idea, i.e. it is reminiscent of the urbanism of Utopian socialists from the first half of the $19^{\text {th }}$ century. Therefore, one can only speak of a specific, very dynamic and flexible city development model that is based on the synergy of economy, science, and public authorities. 

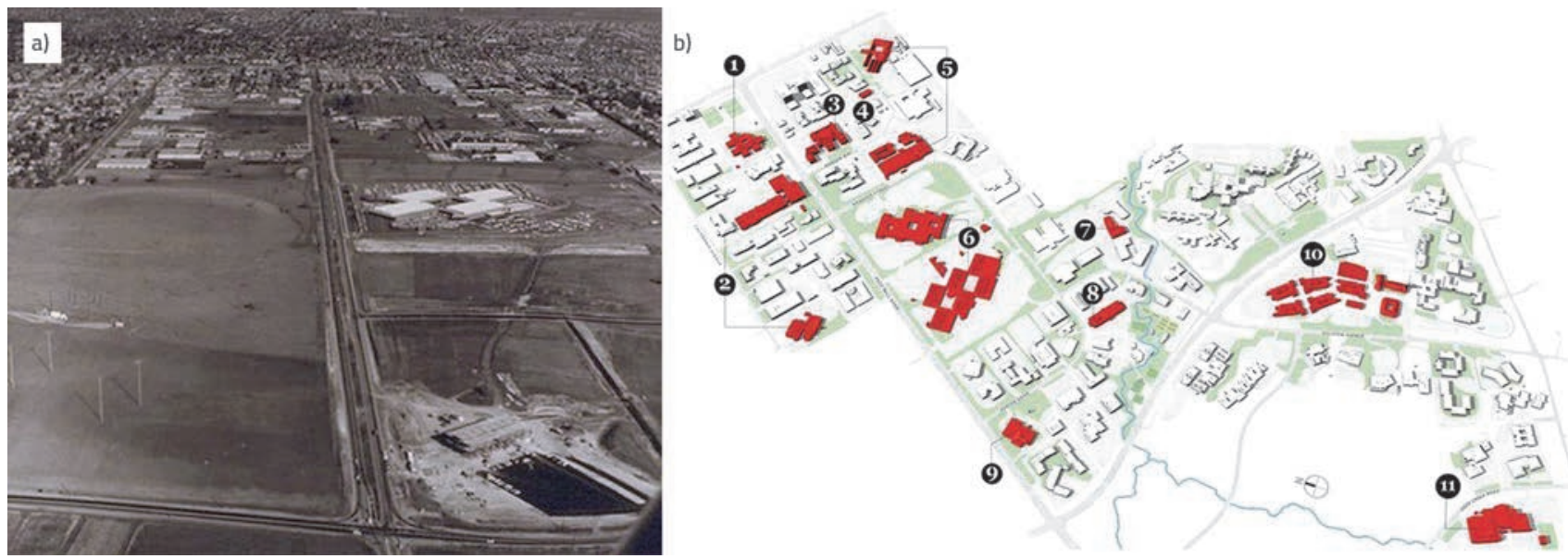

Figure 1. a) Aerial photograph of Stanford Industrial Park around 1950; b) Map of Stanford Industrial Park today [12a,12b]

Unlike Silicon Valley, which came to existence rather spontaneously, the governments, universities and private sector around the world have embraced and used, as from 1980s, this new urban typology aimed at providing a proper environment that inspires innovation [14]. Technopoles have attracted attention because they have successfully linked a supportive environment, an intensively adaptable economy, and the use of technology, which are fundamental elements for ensuring quality of life in urban areas [15]. At the same time, the migration of rural population to cities has imposed an increasing pressure on cities worldwide. Such a situation points to the need to transform cities in order to properly respond to the increasing economic, social and other demands that must be met to enable survival of the city as a unique human-friendly eco-system [16].

In response to this challenge, the concept of sustainable development was globally recognized at the UN Human Environment Conference held in Stockholm in 1972. Although the term was not explicitly stated, the international community agreed with the idea (which later became the basis of sustainable development) that development and the environment, hitherto separate topics, could be managed in a mutually beneficial way. 1987 Report of the World Commission for the Environment and Development, called The Brundtland Commission (named after its chairwoman, Mrs. Gro Harlem Brundtland), has introduced what is today considered as a "classic" definition of sustainable development: "development that meets the needs of the present without compromising the ability of future generations to meet their own needs" [17]. At the UN Conference on Human Environment and Development held in Rio de Janeiro in 1992, sustainable development was recognized as a major challenge that has remained unsolved to this day [18].

The concept of a smart building is very simple in its nucleus: it has a starting point in the desire / need to control living conditions of the environment in which we live, which is the reason for the development of automated heating, cooling and ventilation systems of buildings. Today, the automation of these systems in a building is a prerequisite for it to become a smart. The first automation systems date back as far as the 17th century when Cornelis Drebbel created a mercury thermostat that could automatically maintain a constant temperature in a room. His invention was one of the first feedbackproviding devices known in history [19]. It was only with the advent of electricity that the conditions for the development of advanced automation were created, albeit with limited control and management capabilities. Thus in 1902 the first air-conditioned space was created at the publishing company Sackett-Wilhelms Lithographing and Publishing Co. in Brooklyn, N.Y [20].

The development of computer science in the $20^{\text {th }}$ century has resulted in modern building automation capabilities we enjoy today, but has also created preconditions for the emergence and further development of the smart building concept, which went beyond the initial climate-regulation function of the building. What was missing at the end of the $20^{\text {th }}$ century was a new paradigm that would link together the growing technology, the concept of sustainable development, and the real problems that cities were facing, so as to become a vision of the city of the future. M. Weiser's work on ubiquitous computing emerged in 1988, in the inspirational setting of the Palo Alto Research Center (aka PARC) in Silicon Valley [21].

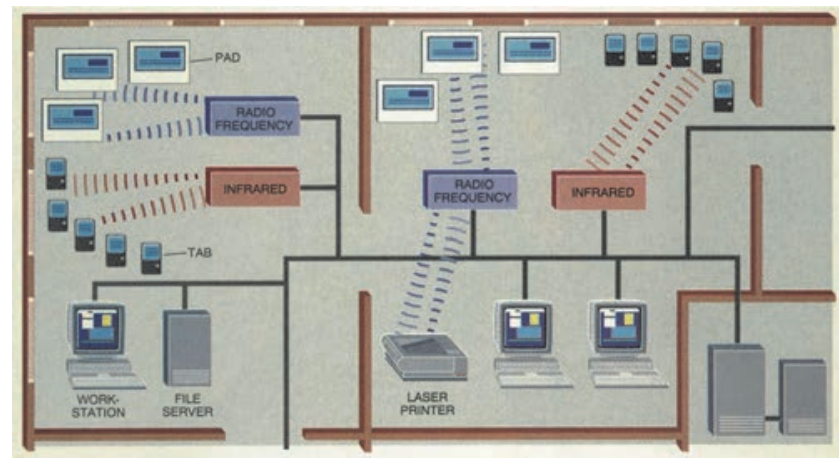

Figure 2. Possible computer connections in a smart home [21]

This paper presents for the first time a vision of the smart home concept where, to put it simply, the improvement of the quality of life is based on enhancing interaction between humans and computers, that is, on the collection, processing and use of data. 
This vision, although based on the home (building), speaks of the ubiquitous computer network and human-computer interaction through its basic postulates: computer, network, device, and human interaction. It has become the platform for creation of the concept of smart city and smart building of today.

\section{Definitions}

Both terms "smart city" and "smart building" were created in the 1980s [22, 23]. The absence of generally accepted definitions that would unambiguously explain these terms [24, 25] s partly due to different scientific fields from which they come, and is also the consequence of changing trends [24, 26]. The problem of the lack of a commonly accepted definition can be divided into several categories:

a) polarization of meaning

b) a holistic or descriptive definition

c) substitution of the word smart.

\section{a) Polarization of meaning}

There is a continuing duality in the understanding of these terms; on the one hand, the technological component - the use of ICT, data and ubiquitous computing - is emphasized, while at the same time it is suggested that the word smart should signify something more than the mere use of ICT. The duality of understanding of these terms does not exist in reality, as stated in the introduction, i.e. technology no longer has a dominant role in the definition of these terms, and their meaning is increasingly linked to the relationship with the user and to the quality of life as the primary goal.

Over the past ten years, the original duality has been replaced by discussions about whether a smart city is also a sustainable city $[22,25,27]$. The answer to this debate is very simple - a smart city has the same goals as a sustainable city. The concept of a smart city has become popular as there are limitations in traditional approaches to sustainability, which are present in the concept of sustainable cities or ecocities. A sustainable city and a smart city are not mutually exclusive. The concept of a smart city is a model (way) of developing a sustainable city. When it comes to developing sustainable cities, it is possible that their development will take longer if it is based on the use of traditional planning tools, without high-tech solutions which are part of a smart city. A smart city has the same goals as a sustainable city or an ecocity - to become more sustainable and to provide better living conditions, which can be achieved by incorporating high-tech solutions into urban tissue [28]. Definitions of the term smart building can be classified into three groups [29]:

- definitions based on performance of the building - they stem from characteristics of the completed building and expectations and increasing demands of the user (and society). Integrated technologies and smart systems are or secondary significance,

- system-based definitions - they are mainly related to technological systems and integrated intelligence that is used in buildings, i.e. they are derived from user response (user's interaction with the system),

- service-based definitions - derived from the quality of service provided to users.

\section{b) A holistic or descriptive definition}

As a rule, definitions are not formulated in a holistic way to describe a term with specific attributes, but are formulated in such a way to describe various material and non-material characteristics of the term, such as:

- 2007 definition by the European Smart Cities Initiative:

A city well performing in a forward-looking way in economy, people, governance, mobility, environment and living, built on the smart combination of environment and activities of self-decisive independent and aware citizens [26] or

- definition by the Buildings Performance Institute Europe (further: BPIE) [30]:

A smart building is highly energy efficient and covers its very low energy demand to a large extent by on-site or district system-driven renewable energy sources. A smart building:

- stabilises and drives a faster decarbonisation of the energy system through energy storage and demand-side flexibility

- empowers its users and occupants with control over the energy flows

- recognises and reacts to users' and occupants' needs in terms of comfort, health, indoor air quality, safety as well as operational performance [25].

\section{c) Substitution of the word smart}

As these terms are extremely popular as concepts, and are used all over the world under different names and inr different circumstances, many variants of the term smart city / building have been generated by replacing the word smart with other alternative adjectives (intelligent, digital, etc.). In order to understand why the word smart is more appropriate than other suggested proposals, it is necessary to explore the meanings of the word smart in different contexts:

- if we are addressing the wider community, the word smart is more appropriate than the word intelligent which is considered elitist. The meaning of the word intelligent is limited to quick thinking and reaction to feedback. For instance, more is required from the smart city / building, i.e. it has to adapt to user needs and to provide custom interfaces [31]

- in the field of urban planning, the word smart is a normative statement that has an ideological dimension. Being smarter entails strategic orientation. Governments and public agencies at all levels are embracing the notion of smart to clarify their new policies, strategies and programs aimed at sustainable development, healthy economic growth, and better quality of life for their citizens [32]

- in marketing, the word smart denotes a focus on the user's perspective [33].

However, the credit for the universal acceptance of the term smart belongs to IBM, which launched the term smart city 
globally in 2008. On November 6, 2008, in the midst of the financial crisis, Sam Palmisano (then IBM's CEO) delivered a speech entitled "A Smarter Planet: A Program for Next Leadership" that had a major impact in the media. In his speech, Palmisano argued that the world and its cities must become smarter in order to become more sustainable and cost-effective. As from the time of this speech, IBM has launched a more extensive "smarter planet" advertising, which has continued to this day [34]. The final question still remains - what is the meaning of the term smart in the context of a city or building. The answer to this question was found in a survey of available databases from publications published on the web [35]. A feature that is mostly repeated in various definitions is that the word smart refers to service-providing systems. As today we are no longer dealing with mere automation of systems, but with systems based on the use of artificial intelligence, such systems are usually referred to as smart service systems. According to Medina Borja [36], a smart service system is a service system capable of learning, dynamic adaptation, and decision making based upon data received, transmitted, and/or processed to improve its response to a future situation.

In the spirit of the aforementioned research, the following working definition is derived in this paper:

Smart city/building is a (sustainable) city/building that uses smart service systems to optimize the resources and use of goods and increase the quality of life of its residents/users.

This definition describes the essence that distinguishes cities / buildings that use smart service systems from those that do not have such systems. It should be emphasized that this definition does not mean that the implementation of smart service systems is the goal. On the contrary, these systems and the ubiquitous computer network are the tools that we use to increase the quality of our living environment. However, the planning or design expertise as related to a city or building is still a prerequisite for successful technological advancement, which has already begun.

\section{Smart city}

From historical perspective, the city of Los Angeles is referred to in literature as the pioneer of smart urbanism as, in 1974, the state-of-the-art computer technology was used in this city to process a large amount of data on housing, traffic, crime and poverty, which served the city to make decisions about future development or town planning strategies [37].

This example was followed by Singapore where, in 1980, an initiative was launched for technological improvement of the city through realisation of an open network of computers - ONE (Open Network for Everyone), which was completed in 1997. At a time when the Singapore Network was completed, the term Smart City started to be increasingly used [38], both in literature and city planning.

Initially, the concept of smart city was related to the modernization of the city's infrastructure through integration of ICT, since there were rare opportunities to start building a new city that could include all aspects of the smart city already at the planning stage. But, even in that early period, there were several symbolic, ambitious examples that had their role model in the urban typology of techno-centres, such as the Multifunction Polis project [39] - a settlement plan that was to be realized in 1994 in Australia (today Adelaide Technology Park) or the projects Cyberjaya and Putrajaya [38] in 1997 in Malaysia (both of them are today technology parks).

Today, globally, most cities are at various stages of preparation, realization or implementation of projects that enable them to approach the smart city concept in particular segments.

Table 1. Smart city characteristics and factors [26]

\begin{tabular}{|c|c|c|}
\hline Features & \multicolumn{2}{|c|}{ Factors } \\
\hline $\begin{array}{l}\text { SMART GOVERNANCE } \\
\text { (Participation) }\end{array}$ & $\begin{array}{l}\text { - Participation in decision-making } \\
\text { - Political strategies \& perspectives }\end{array}$ & $\begin{array}{l}\text { - Public and social services } \\
\text { - Transparent governance }\end{array}$ \\
\hline $\begin{array}{l}\text { SMART PEOPLE } \\
\text { (Social and Human Capital) }\end{array}$ & $\begin{array}{l}\text { - Flexibility } \\
\text { - Creativity } \\
\text { - Cosmopolitanism/Open-mindedness } \\
\text { - Participation in public life }\end{array}$ & $\begin{array}{l}\text { - Level of qualification } \\
\text { - Affinity to life-long learning } \\
\text { - Social and ethnic plurality }\end{array}$ \\
\hline $\begin{array}{l}\text { SMART MOBILITY } \\
\text { (Transport and ICT) }\end{array}$ & $\begin{array}{l}\text { - Availability of ICT-infrastructure } \\
\text { - Sustainable, innovative and safe transport systems }\end{array}$ & $\begin{array}{l}\text { - Local accessibility } \\
\text { - (Inter-)national accessibility }\end{array}$ \\
\hline $\begin{array}{l}\text { SMART ECONOMY } \\
\text { (Competitiveness) }\end{array}$ & $\begin{array}{l}\text { - Innovative spirit } \\
\text { - Entrepreneurship } \\
\text { - Economic image \& trademarks } \\
\text { - Productivity }\end{array}$ & $\begin{array}{l}\text { - Flexibility of labour market } \\
\text { - International embeddedness } \\
\text { - Ability to transform }\end{array}$ \\
\hline $\begin{array}{l}\text { SMART ENVIRONMENT } \\
\text { (Natural resources) }\end{array}$ & $\begin{array}{l}\text { - Attractiveness of natural conditions } \\
\text { - Sustainable resource management }\end{array}$ & $\begin{array}{l}\text { - Pollution } \\
\text { - Environmental protection }\end{array}$ \\
\hline $\begin{array}{l}\text { SMART LIVING } \\
\text { (Quality of life) }\end{array}$ & $\begin{array}{l}\text { - Cultural facilities } \\
\text { - Health conditions } \\
\text { - Individual safety } \\
\text { - Housing quality }\end{array}$ & $\begin{array}{l}\text { - Education facilities } \\
\text { - Touristic attractiveness } \\
\text { - Social cohesion }\end{array}$ \\
\hline
\end{tabular}


Physical development of the concept was accompanied by theoretical refinement of the concept but, for its full understanding and general acceptance, the description of the city's characteristics, defined at the beginning of the century in 2007, was more significant. In its Report [26], the European Smart Cities Initiative defined the concept of smart cities and identified six key features with 33 key factors, as shown in the table 1.

Smart city settings formulated in this way define fields of action that are not based solely on technological considerations and allow adaptation of urban development action plans to local circumstances. These characteristics have subsequently been used in numerous studies to develop performance indicators $[40,41]$ and more elaborate frameworks and strategies in which smart cities development goals are set. However, it is unclear why there is no mention of the quality of urban planning as one of essential elements of the quality of built environment. In buildings, quality is recognized as attractive, but the quality of urban spaces, and consequently of buildings, is a consequence of the quality of planning solutions.

Although a new definition of a smart city - describing the smart city realisation model - was proposed in 2014 [24], the characteristics and factors (from 2007) have been retained in their original form.

Present-day general urban development goals have been set on the global level. In this respect, the EU development policy goals are determined by the agreement adopted at the Paris Climate Conference (COP21) in 2015, and by the UN Sustainable Development Agenda, approved in the same year [42].

The Paris Agreement recognized the role of cities and called for action to reduce greenhouse gases and adapt cities to climate change. Up to this day this agreement has been ratified by 186 out of the 197 signatory countries that produce $89.38 \%$ of negative environmental impacts. As the United States has applied for withdrawal from the agreement, which enters into force on 1 November 2020, there will be 185 signatory countries left with $71.49 \%$ of negative environmental impact after that date [43].

According to the UN Sustainable Development Agenda, it is necessary to ensure access to a secure, affordable and sustainable transport system, to improve an inclusive and sustainable urbanization, and to reduce environmental impact of cities per capita. In this respect, the Energy Union and the Energy and Climate Policy Framework for 2030 have established ambitious European Union (EU) commitments to:

- reduce greenhouse gas emissions lat least $40 \%$ by 2030),

- increase the share of renewable energy consumed (at least $27 \%$ ), and

- save at least $27 \%$ energy and to consider the idea of "30\% savings on the EU level"

- increase Europe's energy security, competitiveness and sustainability [44].
Also, to make urban areas sustainable, the Smart Cities Initiative is supported and encouraged, as the role of smart city projects is extremely important. The key goal of smart city projects is to improve sustainability of the city and the quality of life of its residents by presenting solutions that are able to solve urban problems in an efficient manner [45].

It is no coincidence that the emphasis of development policies is on energy and climate, as the two themes are causally linked. Mitigating the greenhouse effect, in addition to conserving energy resources, indirectly (positively) affects the state of the environment and achieves urban sustainability postulates. In this way, the stated objectives cover more than one characteristic of a smart city. However, without a smart service-providing system, instead of a smart city, we get only a sustainable city.

This fact is important when developing initiatives and strategies for development because a well-designed approach, involving a set of small steps, can be used to match or even exceed concentration on one feature of the city only. The measures by which a sustainable city becomes smart have been broadly defined based on the implementation of a smart service system, the fragments of which can be found in many features of a smart city. These measures include:

- Use of resources: manufacturing, storage and consumption of energy; use of sustainable energy sources, waste management, water management, environmental protection

- Management: managing city systems, such as transport system, balancing consumption of energy or drinking water,

- Control and safety: supervision and control of public spaces, traffic systems, safety

- Connectivity: smart service systems networking at various levels - with other buildings, neighbourhoods or cities - IoT, customer interaction (real-time communication / notifications, smart service systems, response to customer requests and habits)

- Mobility: E-mobility (e-vehicle charging systems), smart transport systems.

This list, as a list of functional areas for smart buildings, is not final, and it has to be continuously evaluated and adapted to technological capabilities and future needs (trends). The

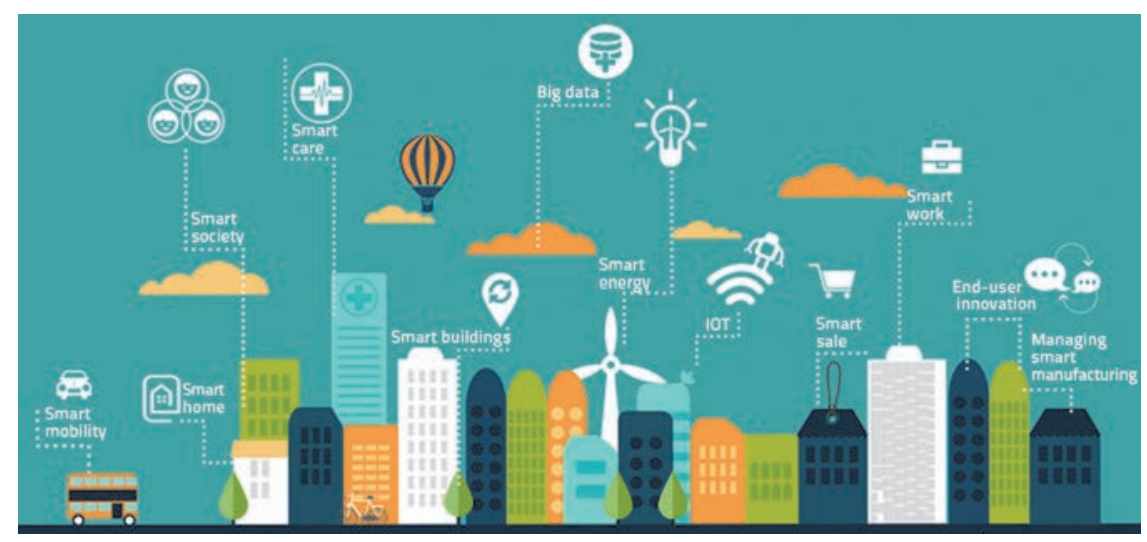

Figure 3. Examples of smart city service systems [46] 
state of development control, involving both the zero phase and monitoring implementation of individual measures, can be valorised using performance indicators. However, in this case it is necessary to use the entire range of indicators covering all characteristics of the city.

Characteristics of the city have been reformulated through development of performance indicators, and their number ranges from 3 (economy, environment, society and culture) to 22 (economy, education, energy, environmental and climate change,

finance, government, health, housing, population and social conditions, recreation, safety, waste management, sports and culture, telecommunications, transport, urban / local agriculture and food supply, urban planning, wastewater and water), depending on a standard/technical regulation/ recommendation [41] that is to be applied in a particular case:

- standard

- ISO 37120:2018 sustainable development of the community - indicators for city services and quality of life,

- ISO 37122:2018 sustainable development in the community - indicators for (draft) smart cities,

- technical regulation:

- ETSI TS 103463 sustainable digital multiservice city regulation

- ITU-T Y.4901/L.1601 use of ICT technology in smart sustainable cities

- ITU-T Y.4902/L.1602 sustainability impacts of ICT technology in smart sustainable cities

- ITU-T Y.4903/L.1603 smart sustainable cities achievement of sustainable development goals

- recommendation:

- UN SDG Sustainable development goals 11 + monitoring.
The figure 4. shows the results of valorisation of the same city by different indicators. It can be seen that the proposed valorisation models, based on the total number of defined indicators (18 104) [41] and the scope of their application, result in uneven valorisation results that are difficult to compare.

The examples of the implemented initiatives show that the most represented ones are those based on the improvement of mobility, network, information flow, and environmental protection. There are several examples of cities that are leading the way by their notable achievements:

- Copenhagen: The Danish capital has received several awards for its work on creating a greener, more attractive and sustainable city. In order to achieve the ambitious goal of becoming the world's first $\mathrm{CO}_{2}$-free capital by 2025 , the city is determined to introduce new and innovative solutions in the fields of transport, waste management, water management heating, and the use of alternative sources of energy [47].

- Singapore: The pioneer of smart city development, this city is characterized by an extensive and rapid urban network that has been developed to control the extremely dense urban traffic, but also to enable residents to monitor energy consumption in their homes. The amount of data and applications available to residents is growing continuously [48].
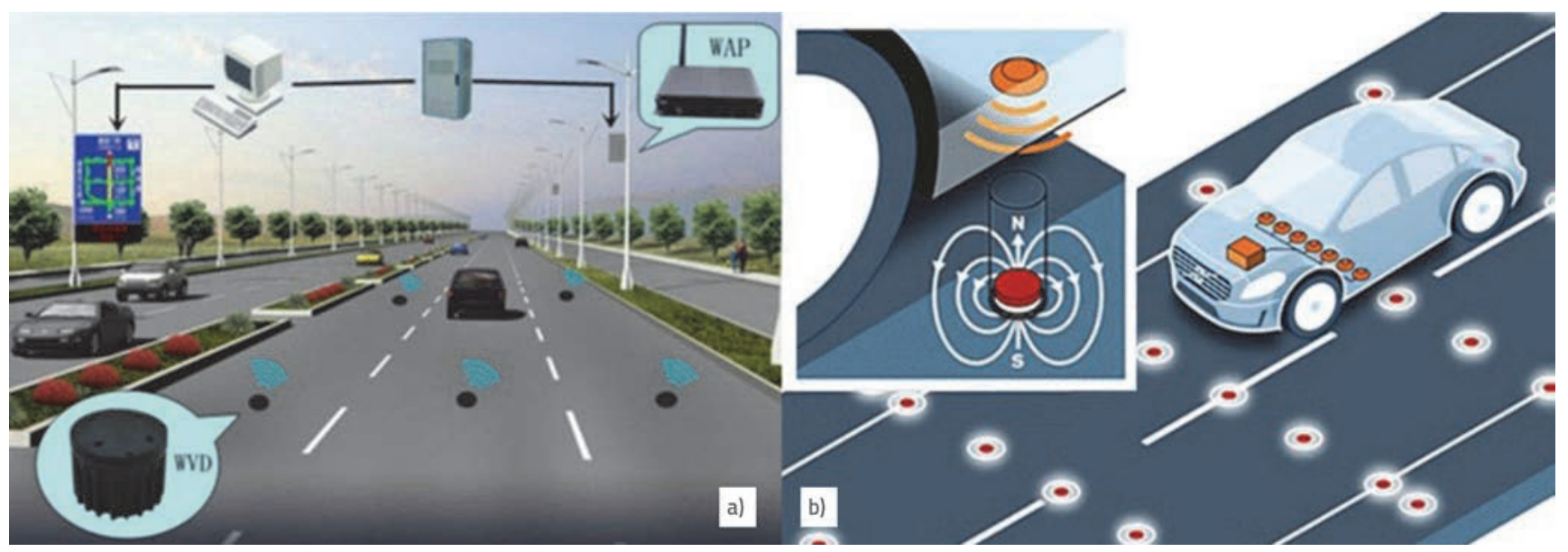

Figure 5. a) Road Sensors; b) EV charging system [51a, 51b] 
a)

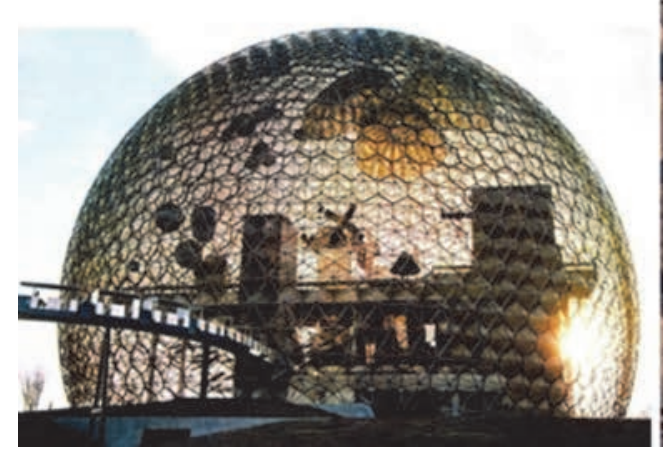

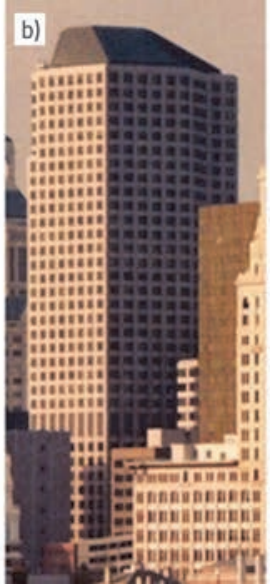

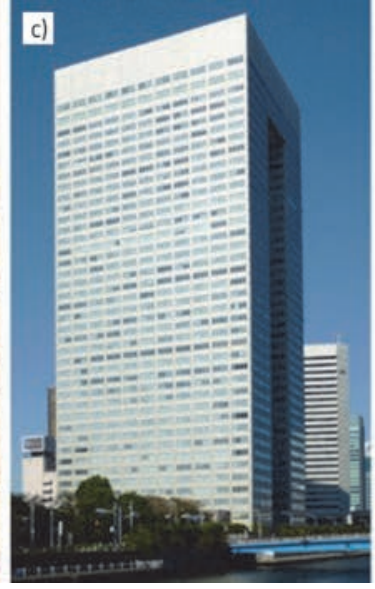

d)

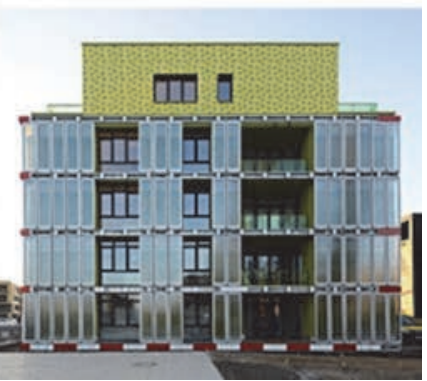

Figure 6. a) US Pavilion; b) City Place, Toshiba Headquarters; c) BIQ Building [55a, 55b, 55c, 55d]

- Vienna: balanced development of this city places it among the top 25 cities in the world in seven out of nine categories [49]. It was rated best in the following categories: quality of transport system, international recognition, use of high technologies and preserved environment, all of which are also typical and easily recognizable elements of the city. In this year the city has received the Global Best Development Strategy Prize [50].

However, apart from introduction of new technical / technological solutions and an innovative approach to solving various challenges, such as those related to urban transport system, the experience of the city will change even more as the solutions currently under development come to life. The integration of sensors and smart service systems that, for example, enables wireless charging of EVs (figure 5), gathering traffic density information, defining road pavement condition, etc. will allow roads, as well as buildings, to become smart.

\section{Smart buildings}

The concept of a smart building, which dates back to the 1980s, was based on the application of complex centralized electronic systems that allow control (automatic management) of buildings, support systems and voice and data communications [23].

Arguably the first precursor of the concept (and application of high technology) is the US Pavilion, designed by architect Buckminster Fuller for the 1967 EXPO World Exhibition in Montreal. One of the first automated climatefriendly envelopes was the dome of this pavilion. The envelope of that geodesic dome was made of transparent acrylic panels, and computer-controlled linen brise-soleils were installed on the inside.
Their position was computer-controlled and adapted to the movement of the sun [52].

However, the distinction of the world's first smart building goes to the City Place Building, which was completed in 1983 in Hartford, Connecticut, USA [53]. The credit goes neither to the architect nor the investor, but to the corporation United Technology Building Systems (UTBS), which has been since 1981 a passionate advocate of the concept of smart (or originally, "intelligent") construction in the United States, and whose air-conditioning system was installed in this building. Specifically, although similar communications and automation systems were used to some extent in other buildings, the term "intelligent building" was not used before creation of the City Place Building in Hartford. The term was commented on in the New York Times: Intelligent in this case means that each building's services will be orchestrated by a computer system and linked by a fibre-optic network.... Functions such as heating, ventilation, lighting, transportation, security, fire protection and, most important, telecommunications and electronic office services will be integrated, providing economies in construction and management [54].

Subsequently, in 1984, a subsidiary of the UTBS Corporation completed the first smart buildings - Tower 49 in New York and

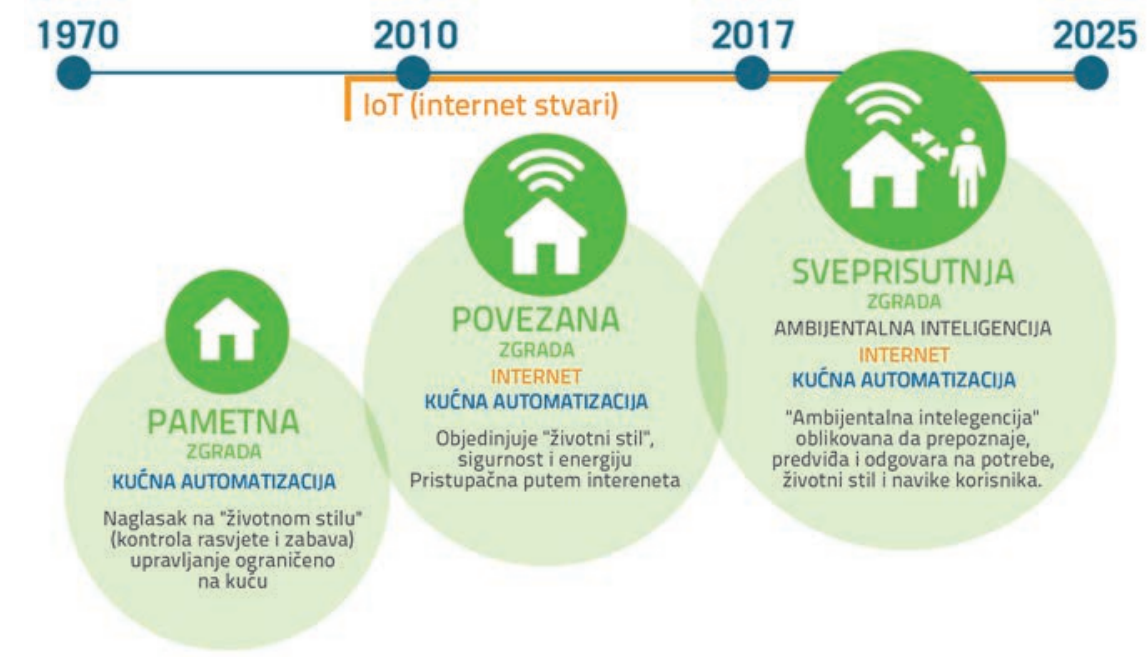

Figure 7. Development of smart building concept [25] 
LTV Centre in Dallas and, in the same year, Toshiba headquarters building was completed in Japan [56] and so the impact of this trend spread worldwide. More recently, the first buildings exploring the possibility of energy self-sufficiency have been realized, such as the 2013 BIQ building in Hamburg [57].

Today's smart building systems have gone beyond this basic stage from the 1980s, mostly thanks to the intensive development of computing.

Without going into a more detailed description of the development of computer systems that have had a significant impact on the evolution of the smart building concept, as such accounts can be found elsewhere in the literature [58], a simplified representation of its development can be shown in the three phases that have taken place in little more than thirty years, figure 7.

As can be seen from the development of smart building concept, the number of its functions is limited only by the level of technological development, and so it must be considered as a "living" system that is continuously evolving and can be upgraded and provided with new functions as appropriate.
Moreover, we see in this segment an impact of the Moore's Law [59], which is a computing term established in the 1970s based on the work of Gordon E. Moore, who predicted that the speed of a processor or the overall processing power of computers would double every two years (the growth rate was stable from 1975 to 2012, but was followed by a slowdown). The fact that utility systems rely on the processing power of computers and can be upgraded only with an increase in such power indicates that, beyond the smart building and smart city concepts, the impact of computing has extended to all segments of the construction industry. Moore's Law also implies that computer systems are subject to continuous development (change), which will be reflected in smart buildings (and smart cities) as well.

Today, all buildings equipped with smart services that helps people manage the building, or that manage the building by themselves, are called I smart buildings. The smart service system represents a new layer that has upgraded the concept of a sustainable (not just energy efficient) home so that it can be used to optimize positive effects of modern installations

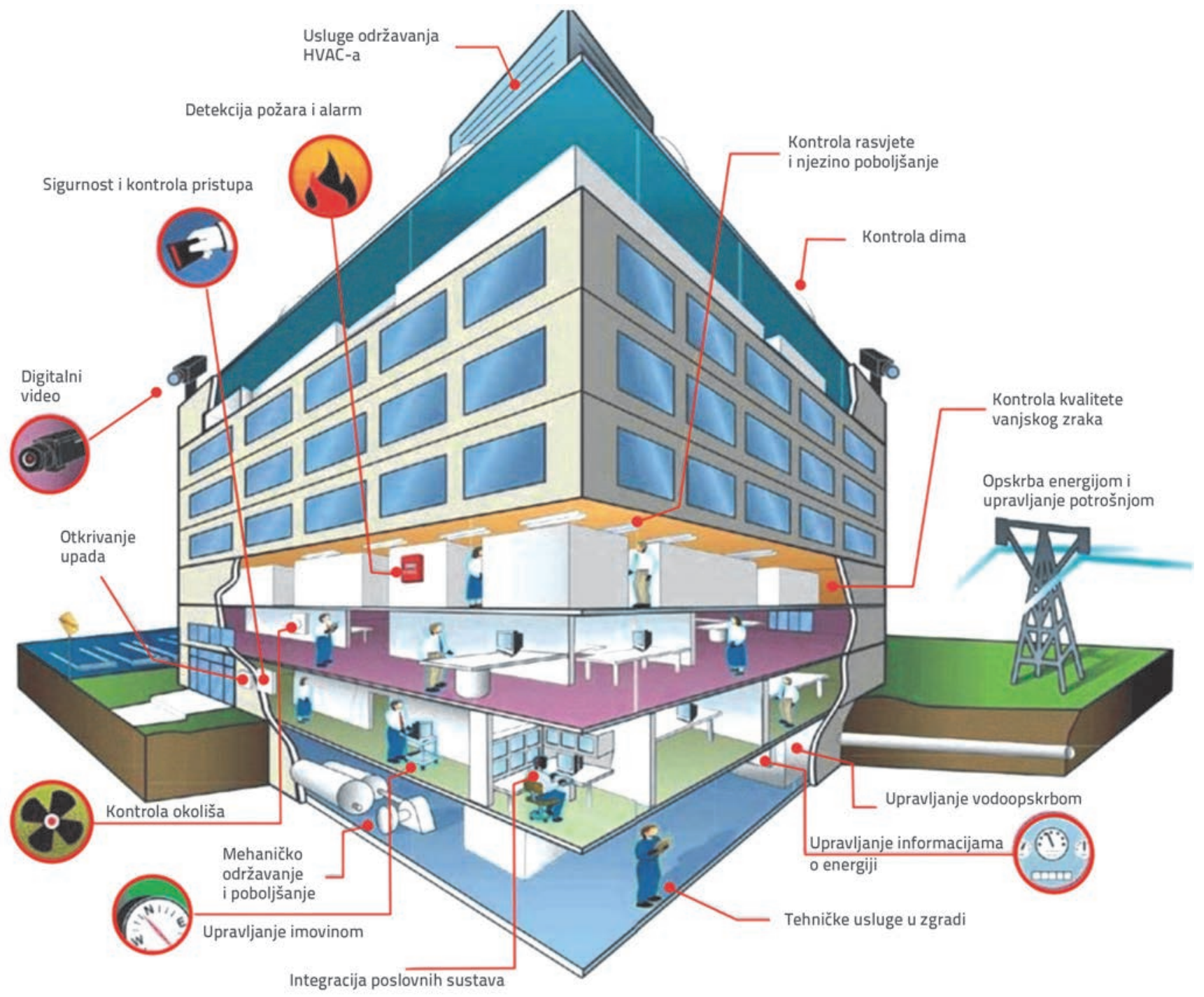

Figure 8. Smart building systems [61] 
Table 2. Features and factors of smart building

\begin{tabular}{|l|l|l|}
\hline Features & \multicolumn{2}{|c|}{ Factors } \\
\hline \multirow{3}{*}{ Performance of buildings } & $\begin{array}{l}\text { - the location } \\
\text { - orientation } \\
\text { - Insolation } \\
\text { - building indicators (area, volume, etc.) } \\
\text { - innovation }\end{array}$ & $\begin{array}{l}\text { - envelope } \\
\text { - materials } \\
\text { - attractiveness } \\
\text { - flexibility }\end{array}$ \\
\hline Resource management & $\begin{array}{l}\text { consumption } \\
\text { - smart monitoring and control of resources }\end{array}$ & - production \\
\hline Dynamic operability & - responsive energy demand & - dynamic cost of resources \\
\hline Use of sustainable energy sources & - sun energy & - air energy \\
\hline Connections and security & - remotesystems that providesustainableenergy sources & - soil energy \\
\hline Flexibility & - internal connection & - responsiveness \\
\hline
\end{tabular}

in buildings (heating, cooling, lighting, etc.) and to improve the quality of the living / working environment in buildings [60]. However, what really distinguishes smart buildings from traditional buildings (which may or may not be equipped with automated devices, such as those for heating or cooling) is the integration of technology, system and structure, and ensuring complete interaction with users. A really smart building collects and systematically analyses the data and, in interaction with users, manages systems integrated in the building, and adjusts building's functions to the actual needs of the users. Also, the impact of these smart service systems can be extended beyond the building - to the control / regulation of its immediate surroundings.

Several suggestions have been put forward with regard to the features or indicators of smart buildings. In 2016, BPIE proposed ten measures to decarbonize the European Housing Fund [62] and, a year later, this was transformed into features of smart buildings [63], which should be based on:

I. High building performance with regard to:

- Reduction of energy demand

- Greater use of locally-produced renewable energy

- Healthy and comfortable indoor environment for occupants
II. Dynamic operability

- Empower occupants with control over the energy flows

- Enhance the ability to optimize comfort, indoor air quality, wellbeing and operational requirements

III. Energy system responsiveness

- Optimum operation of connected energy systems and district infrastructures

According to proposed measures and characteristics of smart buildings, several studies have been developed to define indicators $[64,65]$ for the valorisation of new buildings, as well as for objective evaluation and assessment of the readiness of existing, traditionally constructed buildings, for renovation in accordance with new requirements.

The above discussion shows that BPIE indicators are clearly focused on the energy performance of buildings, i.e. that they are fully in the spirit of the EU development goals, as evidenced, for example, by the change of EU Directive 2010/31 / EU on the energy performance of buildings and Directive 2012/27 / EU on energy efficiency. The change was made to ensure fulfilment of the EU targets for increasing the share of renewable energy in consumption, and for saving energy in use [66].
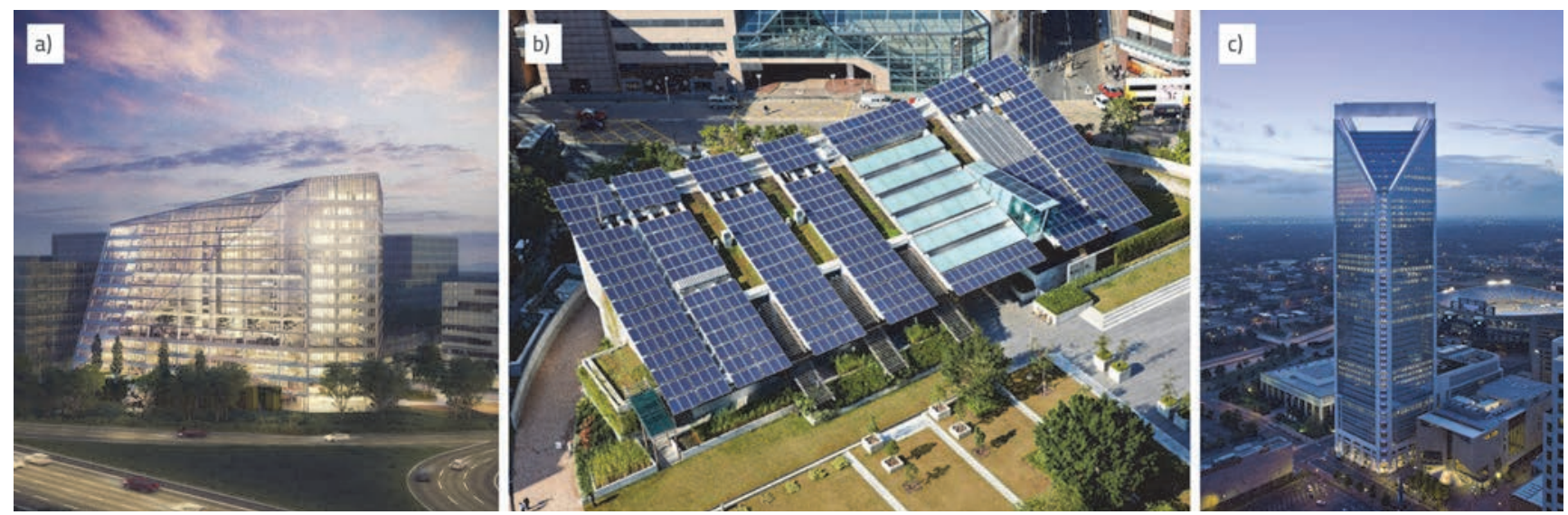

Figure 9. Smart buildings: a) The Edge; b) Mansion ZCB; c) Duke energy centre [70a, 70b, 70c] 
Table 2 shows the characteristics and factors of a smart building obtained by the analysis and systemisation of the above mentioned measures [62], characteristics [63], and indicators for assessing readiness of the existing building stock for adaptation $[64,65]$.

Requirements arising from the very features of smart buildings can be met using available construction materials and construction technologies. However, continuous development of the smart building concept requires further investment in the research and development of new (smart) materials and innovativeness. Examples of recently constructed smart buildings are:

- The Edge, a commercial building in Amsterdam, has more than 30,000 sensors connected to the loT building management system. The system measures the movement, temperature and light level and adjusts its operation based on the occupancy of the space. The Edge uses about $70 \%$ less electricity compared to an average office building [67].

- ZCB Mansion, the first 0-carbon building in Hong Kong, combines elements of a passive house with high-efficiency energy systems (HVAC and BMS) in order to achieve the energy + status that goes beyond energy-neutral building, and generates the quantity of electricity that exceeds the planned consumption. The BMS system controls the building and has approximately 2,800 sensors [68].

- The Duke Energy Centre in Charlotte, North Carolina, has automated systems for managing energy consumption, air conditioning, and lighting. The building also has underground water storage tanks and systems for monitoring precipitation and evaporation rates in order to optimize water consumption for the roof garden and the surrounding open space [69].

\section{Integration of smart service systems in smart cities/buildings}

The incorporation of ubiquitous computing technology is based on the integration and systematic networking of smart service systems that manage buildings and cities, and on their interaction with users.
The first step was to create and materialize the Internet of things (IoT) - connecting, for example, home appliances to the network and enabling interaction with the building or city system or with the user. IoT is defined as a global infrastructure for the information society, enabling advanced services by interconnecting (physical and virtual) things based on existing and evolving interoperable information and communication technologies [71].

The next step is to systematically equip buildings / buildings with different sensors and devices that will, together with loT, enable data collection / exchange, processing / response to the data collected, as well as further interaction with users.

Since the human population of the planet was outnumbered by the number of smart devices ten years ago, and as the number of such devices is expected to grow up to nearly 31 billion [72] by 2020 , the image of the urban landscape they form would approximately resemble the image of the city, figure 10 .

The major benefit of the urban intelligent system and smart building networking is the optimization of city infrastructure systems (energy, water, traffic). The features of such integration and system interaction have so far been limited to data transfer technology, which has changed with the advent of the $5 \mathrm{G}$ network, in which the data transfer rate suffices for the introduction of, for example, autonomous vehicle transport. It is to be expected that this speed standard will soon be increased, enabling further development and interaction of these systems.

While not neglecting the broader social and technological implications of loT development, it is also necessary to place a proper emphasis on the synergic relationship between the smart systems of smart cities and those of smart building(s) Although these effects are currently investigated in many fields, it must be noted that the synergy of urban systems (infrastructure, transport, administration, etc.) is needed for optimum realisation of such projects. In fact, in recent times entire city districts or city blocks are already being built as smart because the synergic effect is in this case far greater than in the case of an individual building. There are currently eight ongoing projects in Europe involving 27 sites (city districts or blocks)

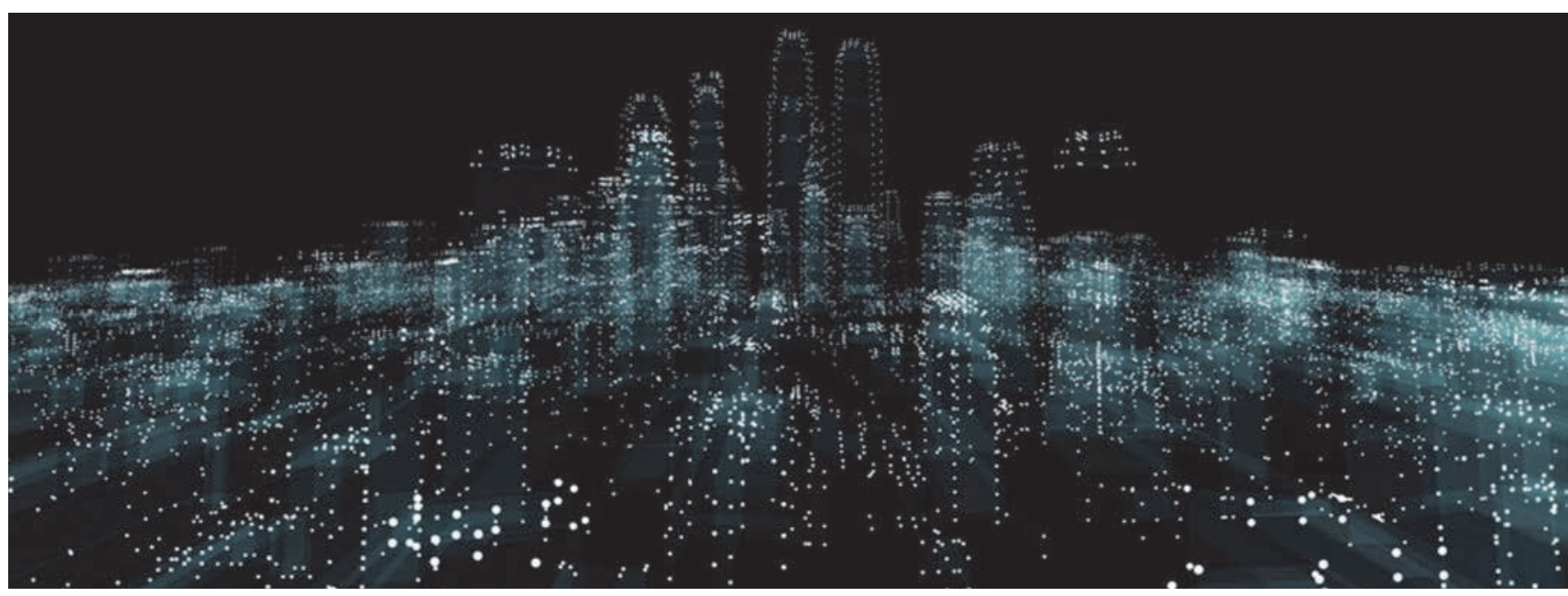

Figure 10. Ubiquitous systems of the smart city [73] 
in 25 cities situated in 13 different countries, where energyefficient urban and community renewal activities are promoted [74]. On the global scale, this number is much higher.

\section{Challenges of development of smart cities and buildings}

In the twenty-first century, growth, economic value and competitive differentiation of cities will increasingly be derived from people and their skills, creativity and knowledge, as well as the capacity of the economy to create and absorb innovation. To compete in this new economic environment, cities will need to better apply advanced information technology, analytics and systems thinking to develop a more citizen-centric approach to services. By doing so, they can better attract, create, enable and retain their citizens' skills, knowledge and creativity [75].

Smart cities and buildings can be distinguished from "traditional" (sustainable) cities and buildings primarily by the new layer - the smart service system. In the context of visible physical changes, smart systems are small in terms of altering the urban structure of the city or physical structure of a building, but the benefit that can be achieved by using smart systems, and by linking them systematically from the level of a building, street or neighbourhood, to the city level, lies in societal and technological changes by which our built environment is improved and a better quality of life is provided to residents/ users. As mentioned in the introduction, when referring to cities, the idea is to improve the existing cities. Full-scale smart cities like Masdar (United Arab Emirates) or PlanIT Valley (Portugal) are still a rare occurrence. The challenges that can be found in the literature $[76,77]$ place emphasis on local problems. However, after analysis, it is possible to present an overview of principal areas in which future development of smart cities and smart buildings will face challenges, such as:

- technological development:

- data acquisition and processing systems (e.g. Big Data), artificial intelligence (computer learning) and device and network (IoT), interoperability

- sustainable use of resources and environmental protection:

- energy efficiency, improvement of city infrastructure systems, improvement of waste management system

- transport system improvement

- traffic management, public transport, smart mobility

- safety:

- privacy, safety of residents and users, security of smart service systems

- human resources:

- education, public government

The prerequisite for the realization of objectives are initiatives and strategies that are understandable, generally accepted, focused on real (local) problems, and that ensure a balanced development of the city. They must be based on interventions that are feasible over a given period, taking into account synergic effects of the proposed initiatives. a) Global and intense strengthening of market relating to smart cities and smart buildings

b) Adjustment of building industry to new market requirements.

\section{a) Global and intense strengthening of market relating to smart cities and smart buildings}

Present-day cities worldwide have become large construction sites. The economic analysis of the market of smart cities and smart buildings shows remarkable estimates concerning their value:

- the market of smart cities (this estimate includes smart buildings) is estimated to have a steady growth rate of $18 \%$ by the year 2025 . It is estimated that in 2020 it will be worth $\$ 1.565$ billion, with a steady growth rate of > $18 \%$ by 2025 [78]

- the share of the construction sector is estimated at $32.5 \%$ of the total [79]

- the market of smart buildings is estimated to have a steady growth rate of $15 \%$ annually, rising from $\$ 233$ billion in 2015 to $\$ 980$ billion in 2025 .

Although EU is not the strongest market, it is estimated that by 2025 it will grow to $24 \%$ [80]. Market value is largely based on the assessment of building inventory. Thus, according to a survey conducted in 2016 [25], it is estimated that approximately $75 \%$ of the Europe's building inventory does not meet energy efficiency standards and that it needs to be upgraded. The situation is similar in the area of infrastructure.

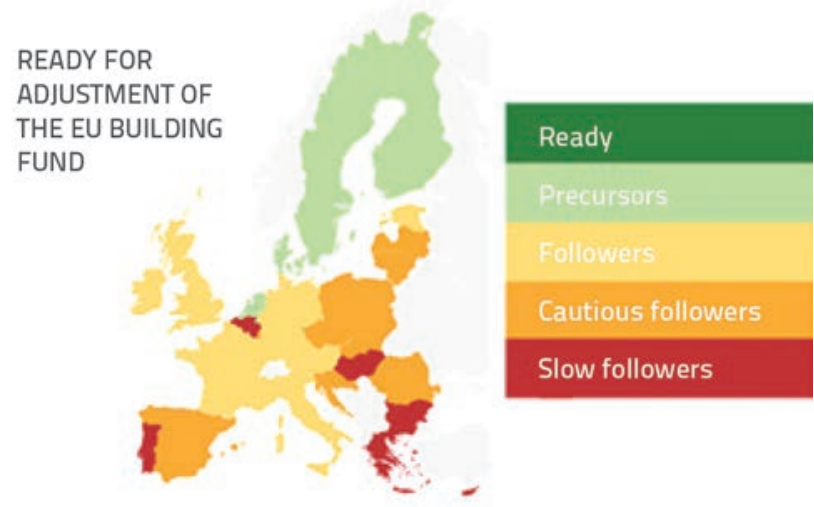

Figure 11. Smart-readiness of building inventory in EU [15]

b) Adjustment of building industry to new market requirements The term smart is related to dynamic and flexible characteristics of the system that is partly based on science. Continuous education of all participants in construction is unfortunately insufficient, and it does not enable adoption of all aspects of the changed project design technology since the use of ICT allows control (management) of all stages of the design and construction and, in particular, optimisation of efficiency of all building systems in use [81].

It is a scientific approach based on the R\&D sector development and promotion of innovation that can offer proper solutions for future development, while also insisting on global competitiveness. 

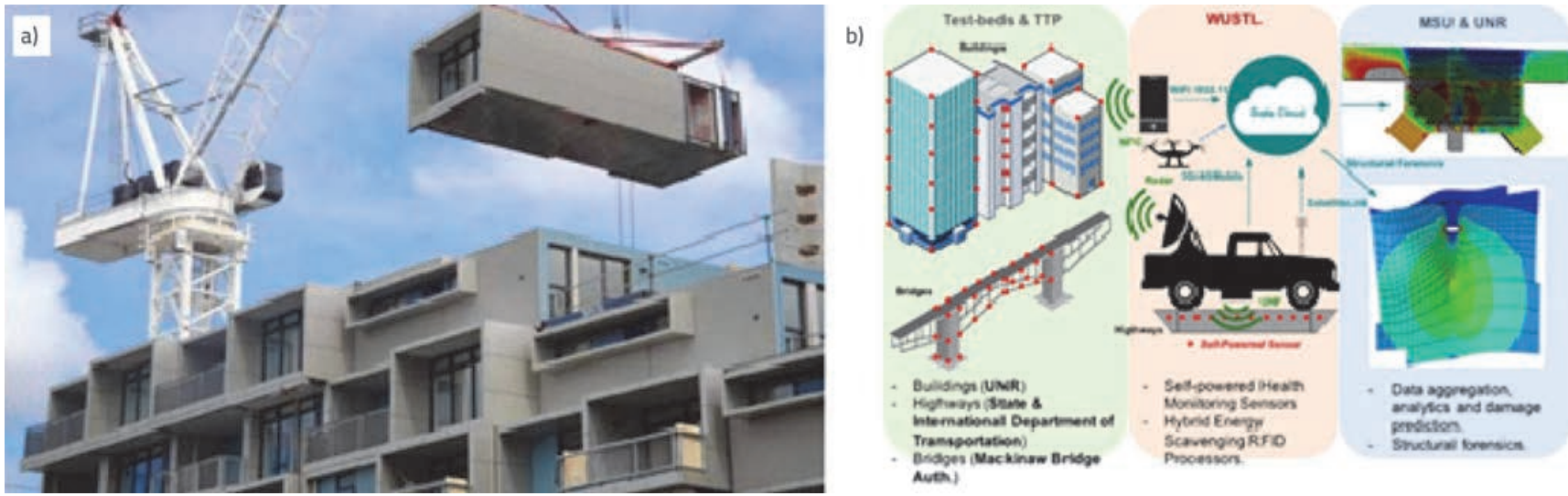

Figure 12. a) construction of prefabricated elements; b) structure surveillance sensors [82a, 82b]

Some of the opportunities offered as a result of technological advancement are:

- construction [83]:

- the emphasis is on reducing proportion of work done insitu,

- use of innovative building technologies,

- development and application of new "smart" materials

- as-built control of the building, and confirmation or correction of data from the Building Information Modelling (BIM) model.

- building use:

- change of management concept.

The use of BIM software packages in early stages of construction simplifies the use of a similar building management software package in use - BMS (Building Management System), which enables real-time monitoring of the building status.

\section{Conclusion}

Over the past 30 years, smart cities and smart buildings have evolved, from the intriguing vision and interesting concept, to a globally present phenomenon whose influence is reflected in numerous direct and indirect changes, not only in the field of construction but also in all aspects of life. Sensors, networks and computers have become part of our everyday life, and their development is constant.

Although changes are visible in the approach to all construction phases and lifecycle, additional changes must be made to allow full integration of these technologies into our living environment. These changes involve greater reliance on research and development activities in the field of new (smart) materials and innovative approach to construction.

When it comes to physical structure, the difference between a smart and "traditional" (sustainable) city / building is manifested, first of all, in the presence of a smart service system, which constitutes just one new layer in the overall urban fabric or structure of a building. Its peculiarity lies in the fact that it is complex, subject to change, and capable of learning (evolving). The development of smart cities and buildings lacks uniform standards. They are primarily needed for the interoperability of the elements of the city / building, but also for objective valorisation of the situation (performance indicators).

Also, technological upgrading of buildings / cities cannot offset shortcomings resulting from poor decision-making in urban space planning or building design. The quality of urban spaces or buildings, however, is ultimately a consequence of the quality of the plan or project. For example, in case of a building, this quality is dependent on optimal orientation, location, and organization of primary functions, and selection of building materials.

\section{REFERENCES}

[1] Global Smart Cities Market to Reach US\$1.56 Trillion by 2020 Finds Frost \& Sullivan, 2014., www.newswiretoday.com/ news/148711/, 02.07.2019.

[2] Tan, Y., Velibeyoglu, K., Martinez-Fernandez, C.: Rising knowledge cities: the role of urban knowledge precincts, Journal of Knowledge Management, 12 (2008) 5, https:/doi. org/10.1108/13673270810902902, 24.08.2019.

[3] Ishida, T.: Digital City Kyoto: Social Information Infrastructure for Everyday Life, Communications of the ACM, September 12, 2000., https://www.researchgate.net/publication/2397855_Digital_ City_Kyoto_Social_Information_Infrastructure_for_Everyday_ Life, 25.06.2019.

[4] Downey, J., McGuigan, J.: Technocities, London: SAGE, 1999.

[5] Poggenpohl, S., et al.: The alphabet highway: literacy in a digital context. Information Design Journal, 8 (1995) 3, pp 267-278, https://doi.org/10.1075/idj.8.3.08pog, 10.06.2019.

[6] Komninos, N., Mora, L.: Exploring the Big picture of smart city research, Scienze Regionali, January 2018, https://doi. org/10.14650/88815, 23.06.2019.

[7] Dameri, R.: Searching for Smart City definition: a comprehensive proposal, International Journal of Computers \& Technology, 11 (2013) 5, pp. 2544-2551, https://doi.org/10.24297/ijct. v11i5.1142, 02.07.2019. 
[8] Clements-Croome, D.J.: What do we mean by intelligent buildings?, Automation in Construction, September 1997, https:// doi.org/10.1016/S0926-5805(97)00018-6, 26.08.2019.

[9] Wigginton, M., Harris, J.: Intelligent Skins, ButterworthHeinemann, Oxford, 2002.

[10] Wong, J.K.W., Li, H., Wang, S.W.: Intelligent Building Research: A Review, Automation in Construction, 14 (2005)., pp. 143-159, https://doi.org/10.1016/j.autcon.2004.06.001, 25.06.2019.

[11] Sturgeon, T.J.: How Silicon Valley Came to Be, u Understanding Silicon Valley: Anatomy of an Entrepreneurial Region, ur. Kenney M., Stanford University Press, 2000., https://www.researchgate. net/publication/228601562_How_Silicon_Valley_came_to_be, 01.09.2019.

[12.a] https://www.flickr.com/photos/businesshistory/2559436745, 05.09.2019.

[12.b] https://www.fastcompany.com/1686634/stanford-universitysunique-economic-engine, 05.09.2019.

[13] Castells, M., Hall, P.: Technopoles of the World, Routledge. London, 1994

[14] Oh, D.S., Phillips, F.: Technopolis, Springer-Verlag London, pp. 43-65, 2014, https://doi.org/10.1007/978-1-4471-5508-9_3, 02.007.2019.

[15] Saxenian, A.: The Genesis of Silicon Valley, Built Environment, Silicon Landscapes: High-technology and Job Creation, Alexandrine Press, 9 (1983) 1, pp. 7-17.

[16] Mega, V., Pedersen, J.: Urban Sustainability Indicators, European Foundation for the Improvement of Living and Working Conditions, 1998., https://www.eurofound.europa.eu/sites/default/files/ ef_files/pubdocs/1998/07/en/1/ef9807en.pdf 10.06.2019.

[17] Report of the World Commission on Environment and Development: Our Common Future, 1987," https:// sustainabledevelopment.un.org/content/documents/5987ourcommon-future.pdf, 23.06.2019.

[18] Bac, D.P.: History of the concept of sustainable development: literature review, https://www.researchgate.net/publication/242219096, 02.07.2019.

[19] Lienhard, J.H.: Engines of our ingenuity - No. 574: CORNELIUS DREBBEL, www.uh.edu/engines/epi574.htm, 25.08.2019.

[20] Green, A.: A Brief History of Air Conditioning, 2015, www. popularmechanics.com/home/how-to/a7951/a-brief-historyof-air-conditioning-10720229/, 25.08.2018.

[21] Weiser, M.: The Computer for the $21^{\text {st }}$ Century, SCIENTIFIC AMERICAN, Sep/1991, pp. 66-75, www.lri.fr/ mbl/Stanford/ CS477/papers/Weiser-SciAm.pdf, 10.06.2019.

[22] Glasmeiera, A., Christopherson, S.: Thinking about smart cities; CAMBRIDGE JOURNAL OF REGIONS, ECONOMY AND SOCIETY, 8 (2015.), pp. 3-12; doi:10.1093/cjres/rsu034

[23] Fantana, G.J., Oae, S.A.: Evolution of Smart Buildings, Procedings of the 2013. International Conference on Environment, Energy and Development, pp. 223-225, 2013. www.inase.org/library/2013/ venice/bypaper/EEEAD/EEEAD-33.pdf, 11.06.2019.

[24] Manville, C., Cochrane, G., Cave, J., Millard, J., Pederson,. Kevin, J., Thaarup, R.K., Liebe, A., Wissner, M., Massink, R., Kotterink, B.: Study - Mapping smart cities in the EU; EU Parliament, Directorate General for the Internal Policies, Policy department A: Economic and Scientific Policy, 2014., www.europarl.europa. eu/RegData/etudes/etudes/join/2014/507480/IPOL-ITRE_ ET(2014)507480_EN.pdf, 12.06.2019.

[25] De Groote, M., Volt, J., Bean, B.: Smart Buildings Decoded; Building Performance Institute Europe (BPIE), 2017.
[26] Giffinger, R., Fertner, C., Kramar, H., Kalasek, R., Pichler-Milanovic, N., Meijers, E.: Smart Cities - Ranking of European medium-sized cities; Vienna University of Technology, 2007.

[27] Albino, V., Berardi, U., Dangelico, R.M.: Smart Cities: Definitions, Dimensions, Performance, and Initiatives, Journal of Urban Technology, 22 (2015) 1, pp. 3-21, Https://doi.org/10.1080/106 30732.2014.942092, 25.06.2019.

[28] Mortensen, J., Rohde, F.J., Kristiansen, K.R., Kanstrup-Clausen, M., Lubanski, M.: Danish Smart Cities: sustainable living in an urban world - An overview of Danish Smart City competencies, Copenhagen Capacity, 2012.(?), http://www.copcap.com/ / media/copenhagen \%20capacity \%20- \%20subsites/documents/ pdf $\% 20$ publications/cleantech \%20pdfs/smart-city-rapportindhold-final-low.ashx, 05.07.2019.

[29] Wang, S.: Intelligent Building and Building Automation, Routledge. New York, 2009.

[30] https://eur-lex.europa.eu/legal-content/HR/TXT/ HTML/ ?uri=CELEX:32019H0786\&from=EN\#ntr67L_2019127HR.01003701-E0067, 27.09.2019.

[31] Marsa-Maestre, I., Lopez-Carmona, M.A., Velasco, J.R., Navarro, A.: Mobile agents for service personalization in smart environments. Journal of Networks, 3 (2008) 5, pp 30-41., https:// doi.org/10.4304/jnw.3.5.30-41 02.07.2019., 05.07.2019.

[32] Center on Governance, SmartCapital Evaluation Guidelines Report: Performance Measurement and Assessment of SmartCapital. Ottawa, Canada: University of Ottawa. Available at http://www. christopherwilson.ca/papers/Guidelines_report_F eb2003.pdf, 10.07.2019.

[33] Klein, C., Kaefer, G.: From smart homes to smart cities: Opportunities and challenges from an industrial perspective. In Proceedings of the 8th International Conference, NEW2AN and $1^{\text {st }}$ Russian Conference on Smart Spaces, ruSMART 2008 (St. Petersburg, Russia, Sep 3-5), www.springerlink.com/content/ d053p7u7g42u573p/, 17.07.2019.

[34] Söderström, O., Paasche, T., Klauser, F.: Smart cities as corporate storytelling, City: analysis of urban trends, culture, theory, policy, action, 18 (2015) 3, pp. 307-320, https://doi.org/10.1080/13604 813.2014.906716, 20.06.2019.

[35] Chiehyeon, L., Maglio, P.P.: Data-Driven Understanding of Smart Service Systems Through Text Mining, SERVICE SCIENCE, 10 (2018) 2, pp. 154-180; https://doi.org/10.1287/serv.2018.0208, 10.06.2019.

[36] Medina-Borja, A.: Smart things as service providers: A call for convergence of disciplines to build a research agenda for the service systems of the future. Service Sci. 7(1):ii-v., 2015., Https:// doi.org/10.1287/serv.2014.0090, 20.06.2019.

[37] Cugurullo, F.: The origin of the Smart City imaginary: from the dawn of modernity to the eclipse of reason; In Lindner C. and Meissner M. (eds) The Routledge Companion to Urban Imaginaries, London: Routledge, 2018.

[38] Vanolo, A.: Smartmentality: The smart city as disciplinary strategy, Urban studies 51 (5) 2014.), pp. 883-898, https://doi. org/10.1177/0042098013494427, 10.06.2019.

[39] Parker, P.: The Multi-Function Polis 1987-97: an International Failure or Innovative Local Project?, Australia-Japan Research Centre, pp. 283, september 1998., https://crawford.anu.edu.au/ pdf/pep/pep-283.pdf, 05.07.2019.

[40] Garau C., Pavan, V.M.: Evaluating Urban Quality: Indicators and Assessment Tools for Smart Sustainable Cities; SUSTAINABILITY, 10 (2018) 3, pp. 575; https://doi.org/10.3390/su10030575, 05.07.2019. 
[41] Huovila, A., Bosch, P., Airaksinen, M.: Comparative analysis of standardized indicators for Smart sustainable cities: What indicators and standards to use and when?; CITIES, 89 (2019), pp. 141-153; doi.org/10.1016/j.cities.2019.01.029

[42] Angelakoglou, K., Nikolopoulos, N., Giourka P., Svensson, I.L., Tsarchopoulos, P., Tryferidis, A., Tzovaras, D.: A Methodological Framework for the Selection of Key Performance Indicators to Assess Smart City Solutions, Smart Cities, 2 (2019), pp. 269-306; https://doi.org/10.3390/smartcities2020018

[43] https://en.m.wikipedia.org/wiki/List_of_parties_to_the_Paris_ Agreement, 28.09.2019.

[44] SWD (2016) 414 Final Commission Staff Working Document: Impact Assessment, Accompanying the Document, Proposal for a Directive of the European Parliament and of the Council Amending Directive 2010/31/EU on the Energy Performance of Buildings; European Commission: Brussels, Belgium, 2016., https://ec.europa.eu/energy/sites/ener/files/documents/1_en_ impact_assessment_part1_v3.pdf, 02.09.2019.

[45] Monzon, A.: Smart cities concept and challenges: Bases for the assessment of smart city projects. In Proceedings of the 2015 International Conference on Smart Cities and Green ICT Systems (SMARTGREENS), IEEE, Lisbon, Portugal, 20-22 May 2015., Https://doi.org/10.1007/978-3-319-27753-0_2

[46] https://iot.electronicsforu.com/expert-opinion/smart-cities/, 27.06.2019.

[47] www.kk.dk, 03.09.2019.

[48] www.live-singapore.com.sg/www.senseable.mit.edu/ livesingapore, 03.09.2019.

[49] https://www.forbes.com/sites/iese/2019/05/21/these-arethe-smartest-cities-in-the-world-for-2019/\#392ef5d01429, 03.09.2019.

[50] https://www.smartcitiesworld.net/news/news/vienna-rankedtop-for-smart-city-strategy-3965, 03.09.2019.

[51.a] http://www.tradesparq.com/products/1789023/New-wirelessvehicle-detection-sensors-for-Intelligent-Traffic-System-totraffic-violation-manufacturers, 01.07.2019.

[51.b] https://www.extremetech.com/extreme/178640-volvodesigns-magnetic-roads-for-cheaper-simpler-self-driving-cars, 01.07.2019.

[52] Massey J.: Buckminster Fuller's cybernetic pastoral: the United States Pavilion at Expo 67, The Journal of Architecture, 21 (2016) 5, pp. 795-815, https://doi.org/10.1080/13602365.2016.12074 33, 10.06.2019.

[53] So, Albert T. and Chan, W. L.: Intelligent Building Systems, Kluwer Academic Publishers, 1999.

[54] https://www.nytimes.com/1983/12/01/business/theintelligent-buildings.html, 26.08.2019.

[55.a] h t t p : // elpais.com/elpais/ $2008 / 08 / 08 /$ album/1218177469_910215.html\#foto_gal_3,02.09.2019.

[55.b] https://hr.wikipedia.org/wiki/Datoteka:City_Place_I,_Hartford,_ CT.jpg, 02.09.2019.

[55.c] https://en.wikipedia.org/wiki/Toshiba\#/media/ File:Hamamatsucho_Building.JPG, 02.09.2019.

[55.d] https://biodesign.eca.ed.ac.uk/building-with-a-biologicalapproach/, 03.09.2019.

[56] Rubin, A.: Intelligent Building Technology in Japan, National Institute of Standards and Technology, NISITIR 4546, 1991., https:// ia601607.us.archive.org/22/items/intelligentbuild4546rubi/ intelligentbuild4546rubi.pdf, 02.09.2019.
[57] Wurm, J.: Developing bio-responsive façades: BIQ House - the first pilot project, The Arup Journal, 2 (2013), pp. 90-95, https:// www.arup.com/perspectives/publications/the-arup-journal, 02.09.2019.

[58] Ghaffarianhoseini, A., Berardi, U., AlWaer, H., Chang, S., Halawa, E., Ghaffarianhoseini, A., Clements-Croome, D.: What is an intelligent building? Analysis of recent interpretations from an international perspective, ARCHITECTURAL SCIENCE REVIEW, 59 (2016) 5, pp. 338-357.

[59] Moor"s law, http://www.mooreslaw.org/, 15.07.2019.

[60] Allen, J.G., MacNaughton, P., Satish, U., Santanam, S., Vallarino, J., Spengler, J.D.: Associations of cognitive function scores with carbon dioxide, ventilation, and volatile organic compound exposures in office workers: a controlled exposure study of green and conventional office environments, ENVIRON HEALTH PERSPECT, 124 (2016), pp. 805-812; http://dx.doi.org/10.1289/ ehp. 1510037

[61] https://blog.econocom.com/en/blog/smartbuilding-and-bms-alittle-glossary/, 05.07.2019.

[62] De Groote, M., Fabbri, M.: Smart buildings in a decarbonised energy system: 10 principles to deliver real benefits for europe's citizens, BPIE, 2016., http://bpie.eu/publication/smart-buildingsin-a-decarbonised-energy-system/, 10.06.2019.

[63] BPIE, ppt: A vision for smart buildings in Europe, 2017. http:// bpie.eu/wp-content/uploads/2017/04/smart-building-wsApril-2017_BPIE.pdf, 10.06.2019.

[64] Verbeke, S., Waide, P., Bettgenhäuser, K., Uslar, M., Bogaert, S.: Supportfor setting up a Smart Readiness Indicator for buildings and related impact assessment - final report; Brussels; 2018., https:// smartreadinessindicator.eu/sites/smartreadinessindicator.eu/ files/sri_secondprogressreport_final_0.pdf, 10.06.2019.

[65] De Groote, M., Volt, J., Bean, F.: Is Europe ready for the smart buildings revolution?; Building Performance Institute Europe (BPIE), 2017.

[66] DIREKTIVA (EU) 2018/844 EUROPSKOG PARLAMENTA I VIJEĆA o izmjeni Direktive 2010/31/EU o energetskim svojstvima zgrada i Direktive 2012/27/EU o energetskoj učinkovitosti, od 30. svibnja 2018., https://eur-lex.europa.eu/legal-content/HR/TXT/ PDF/?uri=CELEX:32018L0844\&from=EN, 04.09.2019.

[67] https://www.ibmbigdatahub.com/blog/3-smart-buildingprojects-demonstrate-it-s-easy-being-green, 02.09.2019.

[68] ttps://architizer.com/blog/practice/materials/7-intelligentbuildings-that-prove-digitally-driven-design-works/, 02.09.2019.

[69] ttps://architizer.com/blog/practice/materials/7-intelligentbuildings-that-prove-digitally-driven-design-works/, 02.09.2019.

[70.a] http://www.cushmanwakefield.nl/en-gb/news/2015/03/ ovg-verhuurt-kantoorruimte-aan-salesforce-in-the-edge, 02.09.2019.

[70.b] https://yp.scmp.com/news/hong-kong/article/97196/zcb-leadsway-creating-low-carbon-initiative-hong-kong, 02.09.2019.

[70.c] http://www.skyscrapercenter.com/building/duke-energycenter/1077, 02.09.2019.

[71] Recommendation ITU-T Y.2060, 06/2012., https://www.itu.int/ rec/T-REC-Y.2060-201206-I, 28.09.2019.

[72] https://www.statista.com/statistics/471264/iot-number-ofconnected-devices-worldwide/. 28.09.2019.

[73] https://www.technative.io/14-pioneering-smart-citiescompanies-to-watch/, 10.06.2019. 
[74] http://mysmartcitydistrict.eu/, 02.09.2019.

[75] IBM: How to transform a city: lessons from the IBM smarter cities challenge, IBM Smarter Cities White Paper, March. 2012., https:// www.ibm.com/downloads/cas/8NEWPLZ1, 03.09.2019.

[76] Nambiar, R., Shroff, R., Handy, S.: Smart Cities: Challenges and Opportunities, in 10th International Conference on Communication Systems \& Networks (COMSNETS), 2018., https://ieeexplore. ieee.org/stamp/stamp.jsp?tp=\&arnumber $=8328204 \&$ tag=1， 01.09.2019.

[77] Chourabi, H., Nam, T., Walker, S., Ramon Gil-Garcia, M.J., Nahon, K., Pardo, T.A., Scholl, H.J.: Understanding Smart Cities:An Integrative Framework, in Hawaii International Conference on System Sciences, Hawaii, 2012.

[78] Global Smart Cities Market to Reach US\$1.56 Trillion by 2020 Finds Frost \& Sullivan, 2014., www.newswiretoday.com/ news/148711/, 26.08.2019.
[79] James, M.: Global Smart City Market, 2013., www.durban.gov.za/ City_Services/Economic_Development/PSIR/Documents/edge. pdf, 26.08.2019.

[80] Smart Building: Energy efficiency application, European Commission, October 2017., https://ec.europa.eu/growth/toolsdatabases/dem/monitor/sites/default/files/DTM_Smart\%20 building \%20- \%20energy \%20efficiency \%20v1.pdf, 26.08.2019.

[81] Del Grosso, A.E.: Examples of Future Potential Smart Civil Structures; ADVANCES IN SCIENCE AND TECHNOLOGY Vol. 56 (2008.), pp 287-296; https://doi.org/10.4028/www.scientific.net/ AST.56.287, , 05.07.2019.

[82.a] http://www.gosmartbricks.com, 05.07.2019.

[82.b] https://phys.org/news/2016-09-smart-infrastructure-sensors. html, 04.07.2019., 05.07.2019.

[83] WEF in collaboration with The Boston consulting group: Shaping the Future of Construction - A Breakthrough in Mindset and Technology; World Economic Forum; 2016. 